\title{
Influence of Atlantoaxial Fusion on Sagittal Alignment of the Occipitocervical and Subaxial Spines in Os Odontoideum with Atlantoaxial Instability
}

\author{
Byung-Wan Choi ${ }^{1}$, Jong-Beom Park ${ }^{2}$, Jong-Won Kang ${ }^{3}$, Do-Gyun Kim² ${ }^{2}$ Han Chang ${ }^{4}$ \\ ${ }^{1}$ Department of Orthopedic Surgery, Inje University Haeundae Paik Hospital, Busan, Korea \\ ${ }^{2}$ Department of Orthopedic Surgery, College of Medicine, The Catholic University of Korea, Seoul, Korea \\ ${ }^{3}$ Department of Orthopedic Surgery, Sun Hospital, Daejeon, Korea \\ ${ }^{4}$ Department of Orthopedic Surgery, Busan Korea Hospital, Busan, Korea
}

\section{Study Design: Retrospective case analysis.}

Purpose: We hypothesized that larger the C1-C2 fusion angle, greater the severity of the sagittal malalignment of C0-C1 and C2C7.

Overview of Literature: In our experience, instances of sagittal malalignment occur at $\mathrm{CO}-\mathrm{C} 1$ and $\mathrm{C} 2-\mathrm{C} 7$ following atlantoaxial fusion in patients with 0 s odontoideum (00).

Methods: We assessed 21 patients who achieved solid atlantoaxial fusion for reducible atlantoaxial instability secondary to 00 . The mean patient age at the time of the operation was 42.8 years, and the mean follow-up duration was 4.9 years. Radiographic parameters were preoperatively measured and at the final follow-up. The patients were divided into two groups $(A$ and $B)$ depending on the $\mathrm{C} 1-\mathrm{C} 2$ fusion angle. In group $\mathrm{A}(\mathrm{n}=11)$, the $\mathrm{C} 1-\mathrm{C} 2$ fusion angle was $\geq 22^{\circ}$, whereas in group $\mathrm{B}$, it was $<22^{\circ}$. The differences in the radiographic parameters of the two groups were evaluated.

Results: At the final follow-up, the C1-C2 angle was increased. However, this increase was not statistically significant $\left(18^{\circ}\right.$ vs. $22^{\circ}$, $p=0.924)$. The $\mathrm{CO}-\mathrm{C} 1$ angle $\left(10^{\circ}\right.$ vs. $\left.5^{\circ}, p<0.05\right)$ and $\mathrm{C} 2-\mathrm{C} 7$ angle $\left(22^{\circ}\right.$ vs. $\left.13^{\circ}, p<0.05\right)$ significantly decreased. The final $\mathrm{C} 1-\mathrm{C} 2$ angle was negatively correlated with the final $\mathrm{CO}-\mathrm{C} 1$ and $\mathrm{C} 2-\mathrm{C} 7$ angles. The final $\mathrm{C} 0-\mathrm{C} 1$ angle $\left(4^{\circ} \mathrm{vs.} 6^{\circ}, p<0.05\right)$ and $\mathrm{C} 2-\mathrm{C} 7$ angle $\left(8^{\circ}\right.$ vs. $\left.20^{\circ}, p<0.05\right)$ were smaller in group $A$ than in group $\mathrm{B}$. After atlantoaxial fusion, the $\mathrm{CO}-\mathrm{C} 1$ range of motion $\left(\mathrm{ROM} ; 17^{\circ} \mathrm{vs} .9^{\circ}, p<0.05\right)$ and the $\mathrm{C} 2-\mathrm{C} 7 \mathrm{ROM}\left(39^{\circ}\right.$ vs. $\left.31^{\circ}, p<0.05\right)$ were significantly decreased.

Conclusions: We found a negative association between the sagittal alignment of $\mathrm{CO}-\mathrm{C} 1$ and $\mathrm{C} 2-\mathrm{C} 7$ after atlantoaxial fusion and the C1-C2 fusion angle along with decreased ROM. Therefore, overcorrection of C1-C2 kyphosis should be avoided to maintain good physiologic cervical sagittal alignment.

Keywords: Os odontoideum; Atlantoaxial instability; Atlantoaxial fusion; Sagittal alignment

Received Jul 1, 2018; Revised Aug 13, 2018; Accepted Sep 6, 2018

Corresponding author: Jong-Beom Park

Department of Orthopaedic Surgery, Uijeongbu St. Mary’s Hospital, College of Medicine, The Catholic University of Korea, 271 Cheonbo-ro, Uijeongbu 11765, Korea

Tel: +82-31-820-3578, Fax: +82-31-847-3671, E-mail: spinepjb@catholic.ac.kr 


\section{Introduction}

The surgical treatment of patients with $\mathrm{C} 1-\mathrm{C} 2$ instability with Os odontoideum $(\mathrm{OO})$ is proven successful when using a combination of fusion and internal fixation technique [1-4]. Indications for surgical treatment can be simply considered in conjunction with the existence of $\mathrm{OO}$ and $\mathrm{OO}$ associated with occipitocervical pain and/or with neurologic signs and symptoms. Other factors that may help determine the need for stabilization and/or decompression include $\mathrm{C} 1-\mathrm{C} 2$ instability, associated deformities, and spinal cord compression.

Several techniques have been used to stabilize the $\mathrm{C} 1$ and $\mathrm{C} 2$ vertebrae in patients with OO [1-11]. The early surgical techniques of $\mathrm{C} 1-\mathrm{C} 2$ fusion include posterior sublaminar wiring techniques, such as the Gallie technique and Brooks-Jenkins technique [5-7]. The transarticular screw fixation technique, introduced by Magerl and Seemann [8], is most typically relied upon because it provides immediate rigid fixation postoperatively and has higher fusion rates than posterior sublaminar wiring techniques [9]. Recently, another $\mathrm{C} 1-\mathrm{C} 2$ posterior fixation technique that uses a $\mathrm{C} 1$ lateral mass screw with $\mathrm{C} 2$ pedicle screw fixation, introduced by Goel and Laheri [10] and modified by Harms and Melcher [11], has become widely accepted as a standard treatment.

Although the clinical results for atlantoaxial instability (AAI) are satisfactory, some patients show postoperative reduction in occipitocervical and subaxial cervical lordosis. Several studies have reported that the appearance of occipitocervical and subaxial sagittal malalignments may be attributable to hyperlordotic C1-C2 fusion [12-14]. However, the condition of most patients in these studies was complicated with the presence of rheumatoid arthritis (RA). Occipitocervical and subaxial sagittal malalignments may develop as part of the natural course in this kind of disease. Therefore, the treatment results in nonrheumatoid arthritic patients who underwent posterior $\mathrm{C} 1-\mathrm{C} 2$ fusion require further investigation.

Therefore, we performed retrospective evaluation of the influence of atlantoaxial fusion on the sagittal alignment of the occipitocervical and subaxial spines in OO patients with AAI.

\section{Materials and Methods}

We retrospectively analyzed 21 patients (10 women and
11 men) who achieved solid fusion for $\mathrm{OO}$ with reducible AAI and were followed up of for at least 24 months. The criteria for C1-C2 fusion were as follows: (1) difference of $<2^{\circ}$ between the flexion and extension lateral radiographs, (2) formation of a bony bridge, (3) no findings of implant failure, and (4) radiolucency in $<50 \%$ of the tissue around the implant [15]. The mean age at the time of operation was 42.8 years (range, 5-73 years), whereas the mean follow-up duration was 4.9 years (range, 2-12 years). Eight patients complained of intractable occipitocervical pain, and 13 complained of myelopathy. All the patients with myelopathy showed intramedullary signal change and retrodental reactive lesions (two cystic and 11 fibrocartilaginous lesions) on magnetic resonance imaging. Magnetic resonance images were produced using a 1.5-tesla unit (Siemens, Munich, Germany) in 13 myelopathy patients. Subjects who (1) had RA, (2) underwent combined surgery on the subaxial cervical spine, (3) had non-union, (4) underwent revision surgery, and (5) had combined cervical deformity of $\leq \mathrm{C} 2$ level were excluded.

All the surgeries were performed by a single senior surgeon. The direction of AAI was defined as the direction of displacement of the spinolaminar line during flexion and extension (Fig. 1). Eleven patients with anterior AAI underwent posterior sublaminar wiring alone, and $10 \mathrm{pa}-$ tients with combined (anterior+posterior) AAI underwent posterior sublaminar wiring and transarticular screw fixation. Autogenous iliac bone graft was used for all patients. The operative techniques used were as described. The patients were placed in the prone position with the skull fixed with a Mayfield clamp. The neck was positioned to

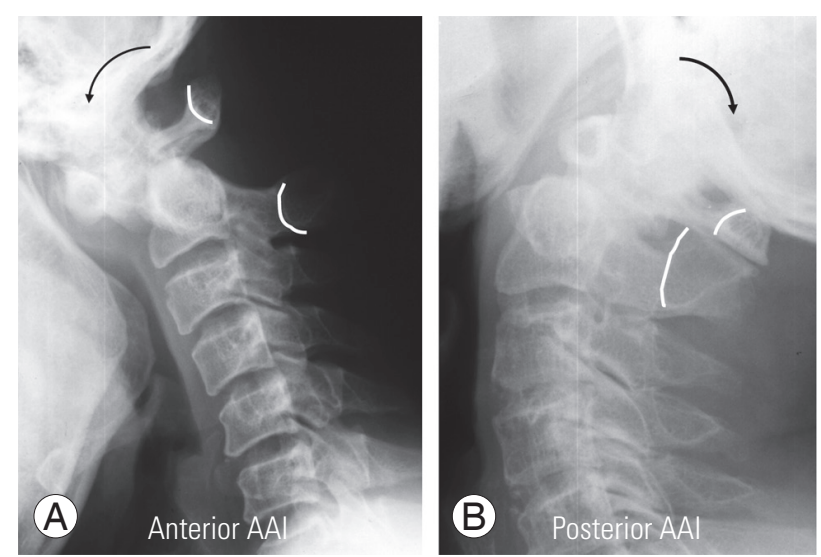

Fig. 1. (A, B) The direction of the AAl was defined as the direction of displacement of the spinolaminar line during flexion and extension. AAl, atlantoaxial instability. 

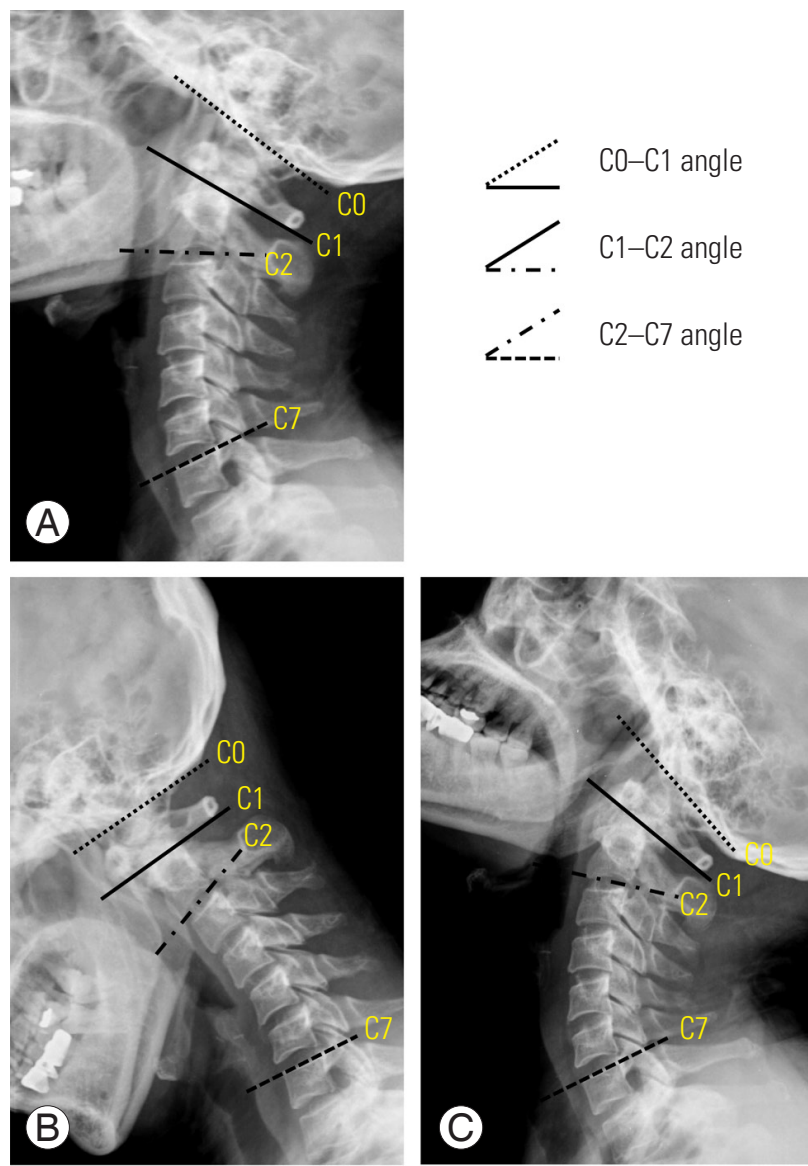

Fig. 2. The C0-C1, C1-C2, and C2-C7 angles were measured on neutral (A) lateral radiographs. The $\mathrm{CO}-\mathrm{C} 1$ angle was measured between the McRae line and the line passing through the centers of the $\mathrm{C} 1$ anterior and posterior arches. The $\mathrm{C} 1-\mathrm{C} 2$ angle was measured between the line passing through the centers of the $\mathrm{C} 1$ anterior and posterior arches and line tangential to the inferior border of the $\mathrm{C} 2$ body. The C2-C7 angle was measured using the Cobb angle between the line on the inferior endplate of $\mathrm{C} 2$ and superior endplate of $\mathrm{C} 7$. The $\mathrm{CO}$ $\mathrm{C} 1, \mathrm{C} 1-\mathrm{C} 2$, and $\mathrm{C} 2-\mathrm{C} 7$ range of motions were measured on flexion (B) and extension (C) lateral radiographs. optimize access by flexing it slightly at the occiput while extending the subaxial spine. We attempted to reduce the $\mathrm{C} 1-\mathrm{C} 2$ articulation during this positioning process. The procedures were assisted with fluoroscopy. A midline incision was made over $\mathrm{C} 1-\mathrm{C} 2$ but distally extended to allow the required drill angulation, and the posterior aspects of $\mathrm{C} 1$ and $\mathrm{C} 2$ were fully exposed. Subperiosteal exposure of the $\mathrm{C} 1$ arch and $\mathrm{C} 2$ posterior elements was performed. Cannulated screws were placed for bilateral transarticular fixation under lateral fluoroscopic guidance. Following screw placement, the modified sublaminar wiring method was used to fix an iliac bone graft. A Philadelphia collar or Halovest was applied for 12 weeks after the procedure.

Plain anteroposterior and lateral radiographs of the cervical spine were recorded preoperatively, postoperatively, and at the final follow-up with subjects in the upright neutral, flexion, and extension positions. Radiographic parameters were measured preoperatively and at the final follow-up. The $\mathrm{C} 0-\mathrm{C} 1, \mathrm{C} 1-\mathrm{C} 2$, and $\mathrm{C} 2-\mathrm{C} 7$ angles were measured on neutral lateral radiographs. The $\mathrm{C} 0-\mathrm{C} 1, \mathrm{C} 1-$ $\mathrm{C} 2$, and $\mathrm{C} 2-\mathrm{C} 7$ range of motions ( $\mathrm{ROMs}$ ) were measured on flexion and extension lateral radiographs (Fig. 2). The differences in the radiographic parameters from before the surgery to that at the final follow-up were evaluated using paired $T$-test. The patients were divided into two groups as per the $\mathrm{C} 1-\mathrm{C} 2$ fusion angle. In group $\mathrm{A}(\mathrm{n}=11)$, the $\mathrm{C} 1-\mathrm{C} 2$ fusion angle was $\geq 22^{\circ}$, whereas that in group $\mathrm{B}$ was $<22^{\circ}$ (Table 1). The differences in the radiographic parameters of the two groups were evaluated using independent $\mathrm{T}$-test. Correlation between the $\mathrm{C} 1-\mathrm{C} 1, \mathrm{C} 0-$ $\mathrm{C} 1$, and $\mathrm{C} 2-\mathrm{C} 7$ angles was analyzed using Pearson test. A $p$-value of $<0.05$ was considered statistically significant.

Table 1. Demographic and radiological data according to final C1-2 fusion angle

\begin{tabular}{|c|c|c|c|}
\hline Variable & Group $A(C 1-2$ angle $\geq 22, N=11)$ & Group B (C1-2 angle $<22, N=10$ ) & $p$-value \\
\hline Age (yr) & $40.98 \pm 9.2$ & $44.8 \pm 14.5$ & 0.36 \\
\hline Sex (male/female) & $7 / 4$ & $3 / 7$ & 0.56 \\
\hline Operation method (PSLW/PSLW+TASF) & $5 / 6$ & $6 / 4$ & 0.41 \\
\hline Preop CO-C1 angle $\left({ }^{\circ}\right)$ & $8.4 \pm 4.4$ & $11.2 \pm 6.7$ & 0.08 \\
\hline Preop C1-C2 angle $\left({ }^{\circ}\right)$ & $17.5 \pm 5.6$ & $19.3 \pm 6.2$ & 0.72 \\
\hline Preop C2-C7 angle $\left(^{\circ}\right)$ & $22.2 \pm 3.4$ & $21.3 \pm 3.4$ & 0.45 \\
\hline Final CO-C1 angle $\left({ }^{\circ}\right)$ & $3.8 \pm 1.2$ & $6.2 \pm 3.4$ & $<0.05$ \\
\hline Final C1-C2 angle $\left(^{\circ}\right)$ & $15.78 \pm 3.8$ & $28 \pm 5.4$ & $<0.05$ \\
\hline Final C2-C7 angle $\left({ }^{\circ}\right)$ & $7.7 \pm 9.9$ & $20.0 \pm 7.2$ & $<0.05$ \\
\hline
\end{tabular}

Values are presented as mean \pm standard deviation or number.

PSLW, posterior sublaminar wiring; TASF, trans-articular screw fixation using Magerl's technique; Preop, preoperative. 

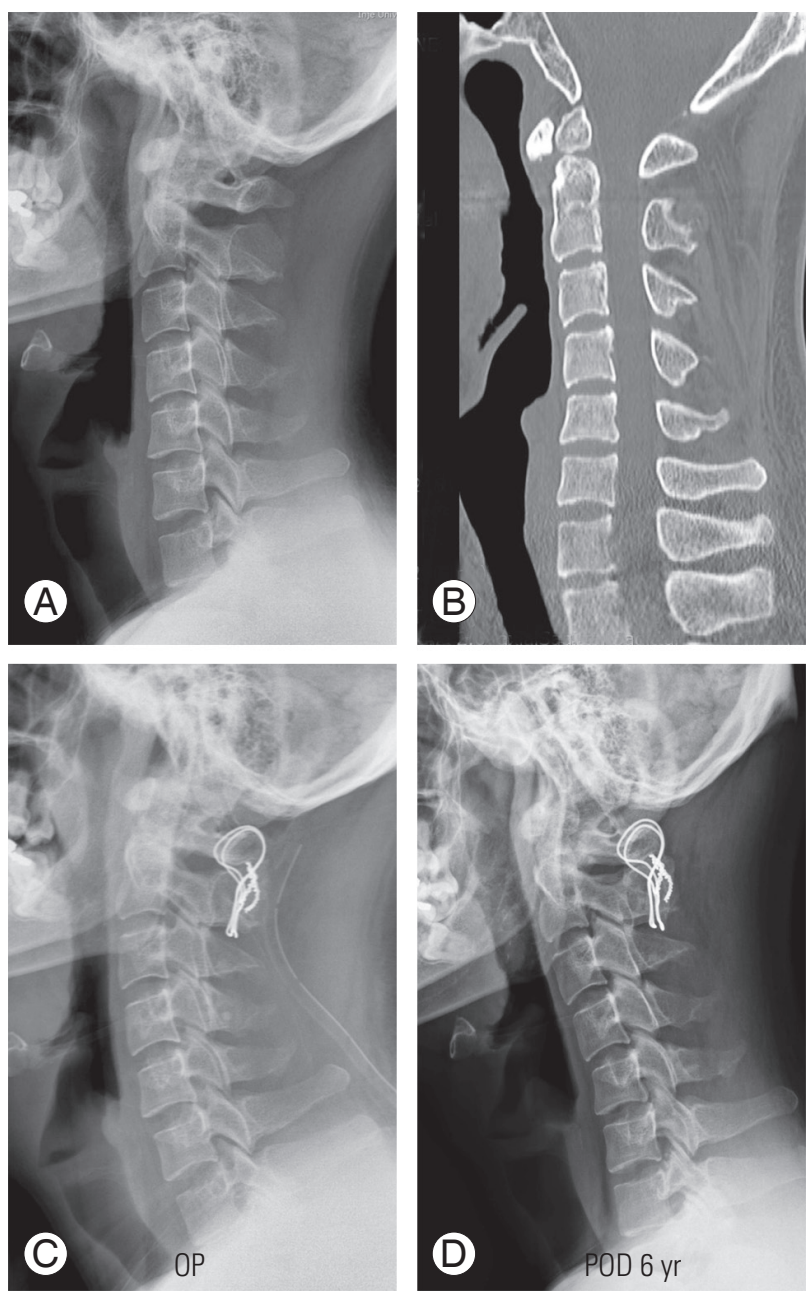

Fig. 3. (A-D) A 44-year-old man with 0s odontoideum underwent $\mathrm{C} 1-\mathrm{C} 2$ posterior sublaminar wiring and fusion. The C1-C2 angle was overcorrected from $23^{\circ}$ preoperatively to $30^{\circ}$ at the final follow-up. The $\mathrm{CO}-\mathrm{C} 1$ angle decreased from $10^{\circ}$ to $9^{\circ}$ preoperatively, whereas the $\mathrm{C} 2-\mathrm{C} 7$ angle decreased from $10^{\circ}$ to $-5^{\circ}$ at 2 years postoperatively. $\mathrm{OP}$, operative; POD, postoperative day.

This retrospective study was approved by the Institutional Review Board of the Uijeongbu St. Mary's Hospital (e-IRB UC17RESI0145) and informed consent was waived.

\section{Results}

The C1-C2 angle was increased from $18.4^{\circ} \pm 5.8^{\circ}$ preoperatively to $21.6^{\circ} \pm 9.1^{\circ}$ at the final follow-up. However, this improvement was not statistically significant $(p=0.924)$. The $\mathrm{C} 0-\mathrm{C} 1$ angle was reduced from $9.73^{\circ} \pm 7.2^{\circ}$ preoperatively to $4.9^{\circ} \pm 2.3^{\circ}$ at the final follow-up $(p<0.05)$. The C2$\mathrm{C} 7$ angle was also significantly decreased from $21.8^{\circ} \pm 13.2^{\circ}$ to $13.3^{\circ} \pm 10.6^{\circ}(p<0.05)$. The final $\mathrm{C} 1-\mathrm{C} 2$ angle was negatively correlated with the final $\mathrm{C} 0-\mathrm{C} 1$ angle (correlation
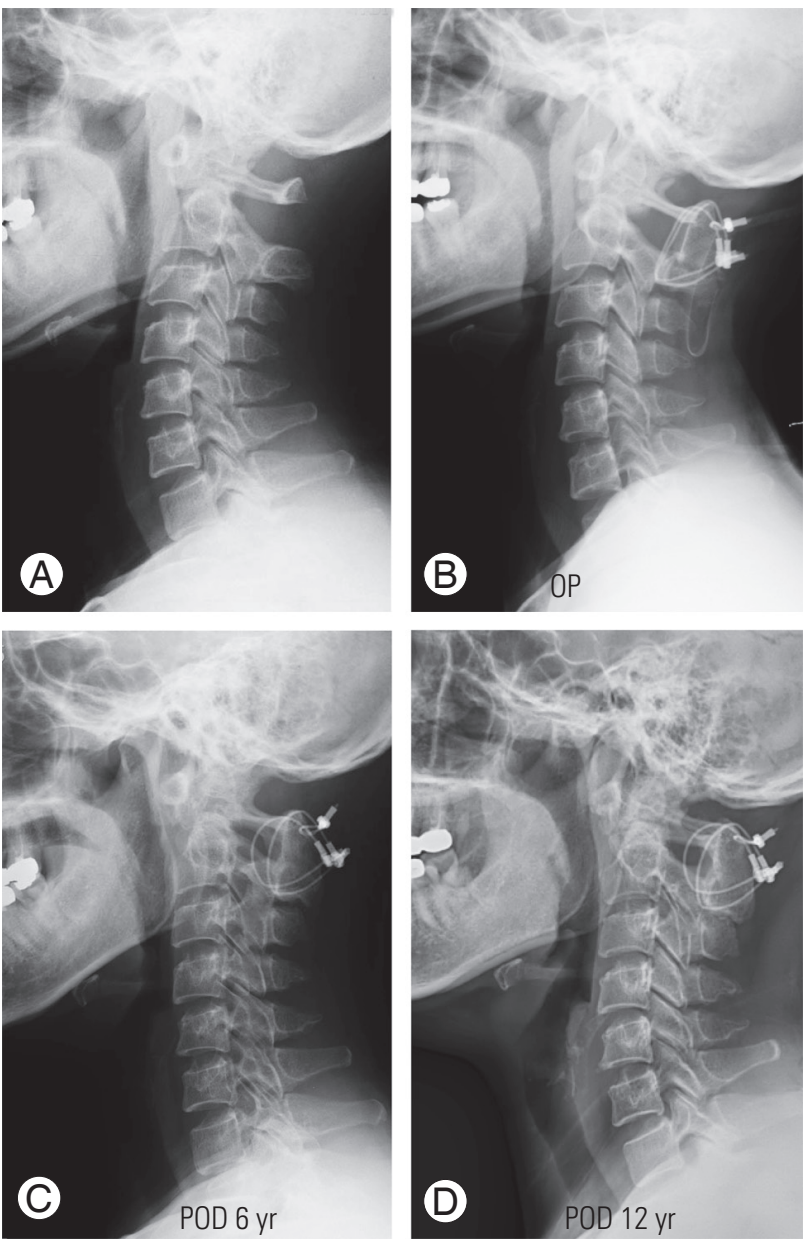

Fig. 4. (A-D) A 36-year-old woman with Os odontoideum underwent $\mathrm{C} 1-\mathrm{C} 2$ posterior sublaminar wiring and fusion. The C1-C2 angle was maintained from $20^{\circ}$ preoperatively to $20^{\circ}$ at 12 years postoperatively. Sagittal alignment was well maintained at a $\mathrm{CO}-\mathrm{C} 1$ angle of $10^{\circ}$ and C2-C7 angle of $22^{\circ}$ at 12 years postoperatively. OP, operative; POD, postoperative day.

coefficient, $-0.547 ; p<0.05)$ and final $\mathrm{C} 2-\mathrm{C} 7$ angle (correlation coefficient, $-0.705 ; p<0.01$ ). Following atlantoaxial fusion, the $\mathrm{C} 1-\mathrm{C} 2 \mathrm{ROM}\left(16.6^{\circ} \pm 9.8^{\circ}\right.$ versus $\left.0^{\circ}, p<0.001\right)$, C0-C1 ROM $\left(16.6^{\circ} \pm 4.4^{\circ}\right.$ versus $\left.8.7^{\circ} \pm 3.8^{\circ}, p<0.05\right)$, and $\mathrm{C} 2-\mathrm{C} 7 \mathrm{ROM}\left(38.9^{\circ} \pm 20.6^{\circ}\right.$ versus $\left.31^{\circ} \pm 15.2^{\circ}, p<0.05\right)$ were significantly decreased. The final $\mathrm{C} 0-\mathrm{C} 1$ angle $\left(3.8^{\circ} \pm 1.2^{\circ}\right.$ versus $\left.6.2^{\circ} \pm 3.4^{\circ}, p<0.05\right)$ and the $\mathrm{C} 2-\mathrm{C} 7$ angle $\left(7.7^{\circ} \pm 9.9^{\circ}\right.$ versus $\left.20.0^{\circ} \pm 7.2^{\circ}, p<0.05\right)$ were smaller in group $\mathrm{A}$ than in group B ( $p<0.05$ for both) (Figs. 3, 4, Table 1).

\section{Discussion}

Atlantoaxial articulation is an anatomic feature with a full ROM in the spine that is dependent for its stability on lig- 
amentous support and the integrity of the odontoid. AAI etiology includes trauma, congenital malformations, OO, RA, malignancy, and skeletal dysplasia. $\mathrm{OO}$ is an anomaly defined as an ossicle with smooth circumscribed margins and no osseous continuity with the C2 body $[1,2,4,16]$. OO patients with instability can be asymptomatic or can present several symptoms, including occipitocervical pain alone, myelopathy, or intracranial symptoms from vertebrobasilar ischemia [16]. Clinically, patients with OO experience severe neck pain and myelopathy due to craniocervical instability and spinal cord compression. In our study, eight of the 21 subjects complained of neck or suboccipital pain, whereas 13 complained of myelopathy.

The surgical techniques to address OO vary from sublaminar wiring to segmental fixation. The early surgical techniques of Brooks and Jenkins [6] and Gallie [5] achieved variable fusion results [17]. Lowry et al. [7] described a $20 \%$ non-union rate with Brooks-type atlantoaxial fusion in patients with OO. To achieve successful fusion, stability reconstruction between $\mathrm{C} 1$ and $\mathrm{C} 2$ combined with bone grafting is necessary. Transarticular screw fixation with strut grafts produces superior fusion rates than those with sublaminar wiring. Based on a large series of 121 patients, nine of whom had OO, Dickman and Sonntag [17] showed a $98 \%$ fusion rate with this technique versus a rate of $86 \%$ with posterior wiring. Moreover, Farey et al. [18] showed a 33\% instability rate with the Gallie technique using immobilization versus $100 \%$ with arthrodesis using transarticular screws in 27 patients, six of whom had OO. To our knowledge, only one study has shown good fusion with this technique [19]. The latest generation of posterior spinal instrumentation is the polyaxial screw-rod system. This approach has been applied to atlantoaxial fusion by Harms and Melcher [11] in a series of 6 patients with OO.

Although there are several reports on $\mathrm{C} 1-\mathrm{C} 2$ fusion, few studies have focused on the association between $\mathrm{C} 1-2$ fixation angle and postoperative subaxial sagittal alignment change. It has been reported that subaxial kyphosis after posterior C1-2 fusion is associated with an increased C1-C2 fusion angle [12,14,19-23]. Yoshimoto et al. [12] documented that in any type of $\mathrm{C} 1-\mathrm{C} 2$ posterior fusion surgery, C1-C2 fixation in a hyperlordotic position led to postoperative subaxial kyphosis. Ishii et al. [20] also found that excessive correction of the $\mathrm{C} 1-\mathrm{C} 2$ angle may cause postoperative hyperlordosis and lead to the development of subluxations of subaxial spine in RA. Huang et al. [21] investigated the cervical sagittal alignment in nonrheumatoid arthritic patients following posterior C1-C2 fusion and identified a correlation between the $\mathrm{C} 1-\mathrm{C} 2$ fusion angle and postoperative cervical sagittal alignment. They also found that posterior $\mathrm{C} 1-\mathrm{C} 2$ fusion in hyperextension may lead to kyphotic change of the atlantooccipital alignment and increase the forward tilt of the cervical spine. Our results also showed smaller final $\mathrm{C} 0$ $\mathrm{C} 1$ and $\mathrm{C} 2-\mathrm{C} 7$ angles in the $\mathrm{C} 1-\mathrm{C} 2$ hyperlordotic group (C1-C2 fusion angle $\geq 22^{\circ}$ ) than in the group with C1-C2 fusion angle $<22^{\circ}$. Further analyses could potentially reveal that increased posterior $\mathrm{C} 1-\mathrm{C} 2$ fusion angle is associated with kyphotic change of occipitocervical and subaxial alignments in patients with $\mathrm{OO}$. Unless the corrected C1$\mathrm{C} 2$ angle is satisfied, surgeons should attempt to make an adjustment during the operation. Matsumoto et al. [22] recommended the application of structural interlaminar spacers instead of autologous bone that can maintain a proper cervical angle.

Thus, there is still no consensus regarding the ideal C1$\mathrm{C} 2$ fusion angle. Nojiri et al. [23] stated that the mean C1$\mathrm{C} 2$ angle in healthy men is $26.5^{\circ}$ and that in healthy women is $28.9^{\circ}$. Moreover, several investigators have noted that the optimum $\mathrm{C} 1-\mathrm{C} 2$ angle for $\mathrm{C} 1-\mathrm{C} 2$ fixation should be approximately $20^{\circ}$ [14,24]. Kato et al. [24] regarded over-reduction as a $\mathrm{C} 1-\mathrm{C} 2$ angle reduction of $>20^{\circ}$ [25]. Huang et al. [21] also commented the change of postoperative $\mathrm{C} 2-\mathrm{C} 7$ angle between final $\mathrm{C} 1-\mathrm{C} 2$ angle less than $20^{\circ}$ group and more than $22^{\circ}$ group. They showed that patients with a correction of $>20^{\circ}$ in the $\mathrm{C} 1-\mathrm{C} 2$ angle are more likely to present a significant postoperative loss of cervical lordosis. We believe that in $\mathrm{OO}$ patients with AAI, $\mathrm{C} 0-\mathrm{C} 1$ and $\mathrm{C} 2-\mathrm{C} 7$ segments have been adapted to the $\mathrm{C} 1-\mathrm{C} 1$ kyphosis for a long time. In the present study, the preoperative $\mathrm{C} 1-\mathrm{C} 2$ angle was $18.4^{\circ}$. Therefore, an acute overcorrection of $\mathrm{C} 1-\mathrm{C} 2$ kyphosis can negatively affect $\mathrm{C} 0-\mathrm{C} 1$ and $\mathrm{C} 2-\mathrm{C} 7$ in the long-term follow-up. Based on our results, we postulate that fusing the $\mathrm{C} 1-\mathrm{C} 2$ angle at $<22^{\circ}$ can decrease the likelihood of sagittal malalignment of $\mathrm{C} 0-\mathrm{C} 1$ and $\mathrm{C} 2-\mathrm{C} 7$.

This study has certain limitations. First, it is a retrospective case series with a relatively small study population owing to the rarity of this pathologic condition. However, to our knowledge, no study has evaluated $>20$ cases of OO, especially using a traditional sublaminar wiring technique and/or transarticular screw fixation. Second, we did not include a control group for comparison, such 
as patients undergoing $\mathrm{C} 1-\mathrm{C} 2$ polyaxial screw fixation. Huang et al. evaluated the relation between the $\mathrm{C} 1-\mathrm{C} 2$ fusion angle and postoperative cervical alignment using C1-C2 segmental fixation [21]. They also reported that over-reduction of the $\mathrm{C} 1-\mathrm{C} 2$ angle and hyperlordotic $\mathrm{C} 1-$ C2 fusion leads to sagittal malalignment. Therefore, the results of the present study are also applicable for conventional C1-C2 segmental fixation technique.

\section{Conclusions}

We found a negative association between the sagittal alignment of $\mathrm{C} 0-\mathrm{C} 1$ and $\mathrm{C} 2-\mathrm{C} 7$ after atlantoaxial fusion and the $\mathrm{C} 1-\mathrm{C} 2$ fusion angle along with decreased ROM. Thus, overcorrection of C1-C2 kyphosis should be avoided to maintain good physiologic cervical sagittal alignment.

\section{Conflict of Interest}

No potential conflict of interest relevant to this article was reported.

\section{References}

1. Klimo P Jr, Kan P, Rao G, Apfelbaum R, Brockmeyer D. Os odontoideum: presentation, diagnosis, and treatment in a series of 78 patients. J Neurosurg Spine 2008;9:332-42.

2. Reilly CW, Choit RL. Transarticular screws in the management of C1-C2 instability in children. J Pediatr Orthop 2006;26:582-8.

3. Gluf WM, Schmidt MH, Apfelbaum RI. Atlantoaxial transarticular screw fixation: a review of surgical indications, fusion rate, complications, and lessons learned in 191 adult patients. J Neurosurg Spine 2005;2:155-63.

4. Ni B, Zhu Z, Zhou F, et al. Bilateral C1 laminar hooks combined with $\mathrm{C} 2$ pedicle screws fixation for treatment of C1-C2 instability not suitable for placement of transarticular screws. Eur Spine J 2010;19:1378-82.

5. Gallie WE. Fractures and dislocations of the cervical spine. Am J Surg 1939;46:495-9.

6. Brooks AL, Jenkins EB. Atlanto-axial arthrodesis by the wedge compression method. J Bone Joint Surg Am 1978;60:279-84.

7. Lowry DW, Pollack IF, Clyde B, Albright AL, Adel- son PD. Upper cervical spine fusion in the pediatric population. J Neurosurg 1997;87:671-6.

8. Magerl F, Seemann P. Stable posterior fusion of the atlas and axis by transarticular screw fixation. In: Kehr P, Weidner A, editors. Cervical spine I. New York (NY): Springer-Verlag; 1987. p. 322-7.

9. Yoshida M, Neo M, Fujibayashi S, Nakamura T. Comparison of the anatomical risk for vertebral artery injury associated with the C2-pedicle screw and atlantoaxial transarticular screw. Spine (Phila Pa 1976) 2006;31:E513-7.

10. Goel A, Laheri V. Plate and screw fixation for atlanto-axial subluxation. Acta Neurochir (Wien) 1994;129:47-53.

11. Harms J, Melcher RP. Posterior C1-C2 fusion with polyaxial screw and rod fixation. Spine (Phila Pa 1976) 2001;26:2467-71.

12. Yoshimoto $\mathrm{H}$, Ito $\mathrm{M}$, Abumi $\mathrm{K}$, et al. A retrospective radiographic analysis of subaxial sagittal alignment after posterior C1-C2 fusion. Spine (Phila Pa 1976) 2004;29:175-81.

13. Oshima S, Sudo H, Ito M, Abumi K. Subaxial sagittal alignment after atlantoaxial fixation techniques. J Spinal Disord Tech 2015;28:E49-55.

14. Yoshida G, Kamiya M, Yoshihara H, et al. Subaxial sagittal alignment and adjacent-segment degeneration after atlantoaxial fixation performed using C-1 lateral mass and C-2 pedicle screws or transarticular screws. J Neurosurg Spine 2010;13:443-50.

15. Kandziora F, Pflugmacher R, Scholz M, et al. Treatment of traumatic cervical spine instability with interbody fusion cages: a prospective controlled study with a 2-year follow-up. Injury 2005;36 Suppl 2:B2735.

16. Rozzelle CJ, Aarabi B, Dhall SS, et al. Os odontoideum. Neurosurgery 2013;72 Suppl 2:159-69.

17. Dickman CA, Sonntag VK. Posterior C1-C2 transarticular screw fixation for atlantoaxial arthrodesis. Neurosurgery 1998;43:275-80.

18. Farey ID, Nadkarni S, Smith N. Modified Gallie technique versus transarticular screw fixation in C1-C2 fusion. Clin Orthop Relat Res 1999;359:126-35.

19. Grob D, Crisco JJ 3rd, Panjabi MM, Wang P, Dvorak J. Biomechanical evaluation of four different posterior atlantoaxial fixation techniques. Spine (Phila Pa 1976) 1992;17:480-90.

20. Ishii K, Matsumoto M, Takahashi Y, et al. Risk factors 
for development of subaxial subluxations following atlantoaxial arthrodesis for atlantoaxial subluxations in rheumatoid arthritis. Spine (Phila Pa 1976) 2010;35:1551-5.

21. Huang JC, Qian BP, Qiu Y, Yu Y, Ni HB. Surgical overreduction and hyperlordotic fusion of $\mathrm{C} 1-\mathrm{C} 2$ joint are associated with cervical sagittal malalignment. Arch Orthop Trauma Surg 2017;137:1631-9.

22. Matsumoto M, Chiba K, Nakamura M, Ogawa Y, Toyama Y, Ogawa J. Impact of interlaminar graft materials on the fusion status in atlantoaxial transarticular screw fixation. J Neurosurg Spine 2005;2:23-6.

23. Nojiri K, Matsumoto M, Chiba K, et al. Relation- ship between alignment of upper and lower cervical spine in asymptomatic individuals. J Neurosurg 2003;99:80-3.

24. Kato Y, Itoh T, Kanaya K, Kubota M, Ito S. Relation between atlantoaxial $(\mathrm{C} 1 / 2)$ and cervical alignment (C2-C7) angles with Magerl and Brooks techniques for atlantoaxial subluxation in rheumatoid arthritis. J Orthop Sci 2006;11:347-52.

25. Toyama Y, Matsumoto M, Chiba K, et al. Realignment of postoperative cervical kyphosis in children by vertebral remodeling. Spine (Phila Pa 1976) 1994;19:2565-70. 